\title{
Levitation and Propulsion for the Magnetically Levitated Conveyance System Using Two Phase Linear Motor
}

\author{
Shunsuke Ohashi Member (Kansai University, ohashi@ipcku.kansai-u.ac.jp)
}

Keywords: magnetically levitation, linear motor, conveyance system

\section{Introduction and Experimental Device}

Magnetically levitated conveyance systems have been developed. These systems have an advantage of carrying load without contacting. So conveyance systems for many applications have been underdeveloped. Most system consists of levitation section and thrust one. Thus we need two facilities to realize contact-less conveyance. We have developed the conveyance system that realizes levitation and propulsion. At first a linear motor with three-phase primary is introduced. Although stabile levitation is obtained, influence of running speed on the levitation characteristics is large. To reduce this disadvantage, we have developed the system with single facility using two phase linear motor. Fig. 1 shows the experimental device. Two phase linear motor winding is set for propulsion and levitation. On the carrier, two iron cores are installed. Copper windings are given on these cores, and a FET device is connected for switching. Principle for levitation is as follows; when air gap between the iron core and linear winding becomes small, switch (FET) is closed. The winding on the core is short circuited, attractive force decreases. If we need more attractive force, switch is opened, and then attractive force increases. Thus we can control air gap by switching the FET connected to the windings on the core. Principle for propulsion is shown. At first, one of the linear windings (Phase A) is excited. Then current of the Phase A decreases and that of Phase B increases. As distribution of the flux is changed, U-shape iron core on the carrier move to right side. Finally current of the Phase A becomes zero, that of the Phase B maximum. Iterating these procedures, the carrier moves.

\section{Result and Conclusion}

Fig. 2 shows levitation characteristics under acceleration for running direction. The levitation gap $g=3.5 \mathrm{~mm}$ is used. When the acceleration of the bogie becomes large, levitation gap is disturbed and little out of directed value. But levitation gap is soon close to the directed value, and the carrier continues the stable levitation.

In this system, levitation and propulsion system are combined. Principle of the levitation and propulsion is shown. Levitation region with each phase excitation state is measured. Using amplitude modulation for the power supply, stable levitation of the carrier with running is given. This system realizes contact-less conveyance. As we need only electrical power for FET switching on the carrier side, power supply system for carrier is not needed. Stable levitation is achieved, and the carrier can run correspond to the frequency of the amplitude modulation. Also under the acceleration, the carrier levitates at directed levitation gap. Stability of levitation is influenced on the control parameters such as switching line and the resistance installed on the parallel of the FET. More stability at a higher velocity and position control method for running direction should be considered for further research.

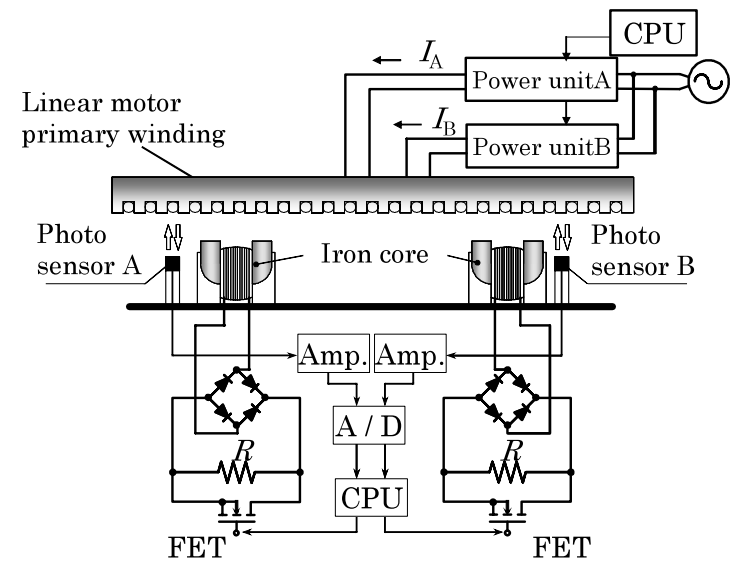

Fig. 1. Experimental device

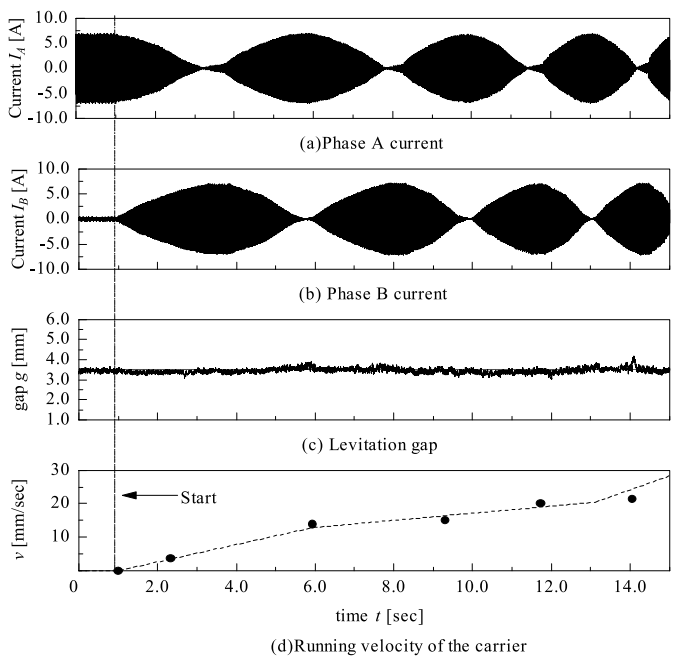

Fig. 2. Levitation with propulsion 


\title{
2 相リニア磁気浮上搬送システムの浮上・推進に関する検討
}

\author{
正 員 大橋 俊介* \\ Levitation and Propulsion for the Magnetically Levitated Conveyance System \\ Using Two Phase Linear Motor
}

Shunsuke Ohashi*, Member

The magnetically levitated conveyance systems have been developed. Most system consists of levitation (and guidance) section and thrust one. We have developed the conveyance system that realizes levitation and propulsion with single facility using two phase linear motor. In this system, levitation and propulsion system are combined. Control method for the propulsion system to get more stability is discussed. To obtain the propulsion force, modulation of the voltage applied on the primary windings is undertaken. Traveling field is generated and the carrier with the secondary iron core can move. Levitation force is given by attractive force between flux generated by the primary windings and secondary iron core. As we need only electrical power for FET switching on the carrier side, power supply system for carrier is not needed. From the experimental results, it is shown that this system realizes contact-less conveyance with various propulsion patterns.

キーワード: 磁気浮上, リニアモータ, 搬送システム

Keywords: magnetically levitation, linear motor, conveyance system

\section{1. はじめに}

磁気浮上システムは非接触で搬送を行うことができるた め, 搬送に伴う摩擦部分がない。よって, 騒音が少なく摩 擦による粉塵発生がないなどの利点から騒音や粉塵などの 発生が好ましくない場所での搬送システムや鉄鋼板の搬送 などさまざまな用途への応用が期待されている(1)(2)。ほと んどのシステムにおいて, 浮上案内と推進系は別々に構成 されているため, 完全非接触搬送を実現するためには浮上 案内および推進の 2 つシステムを用意する必要がある ${ }^{(3)}$ 。 本研究では浮上案内および推進を 1 次側リニアモー夕巻線 と 2 次側 (搬送車側) に取り付ける鉄心により実現する搬 送システム ${ }^{(4)}$ を取り上げる。まず 1 次側に 3 相巻線を用い たシステムを考案，実験装置を作成したが，巻線に移動磁 界が発生する移動モードと, 搬送車が推進方向には停止し 浮上状態になる浮上停止モードにおいて吸引力の差が非常 に大きいため, 浮上停止状態から円滑に移行することが困 難であった。そこで, 1 次側 3 相巻線を 2 相にすることで 搬送車が地上で停止している状態から浮上し, 走行するま で安定した浮上の実現をはかった。本論文では推進を伴う

\footnotetext{
$*$ 関西大学工学部先端情報電気工学科

干 564-8689 吹田市山手町 3-3-35

Department of electrical and computer sciences, Kansai University

3-3-35, Yamate-cho, Suita, Osaka 564-8680
}

浮上についてとりあげ, 推進方法について説明し, 推進特 性, その際の特性について述べる。

\section{2. 実験装置}

〈2・1〉 1 次側リニアモータ巻線 図 1 にシステム構 成を示す ${ }^{(5)}$ 。2 2 相リニア巻線が 1 次側鉄心に施されている。 2 次側としてU 型鉄心が搬送車に取り付けられている。こ の鉄心はリニアモータの 2 次側としてだけでなく, 吸引型 浮上システム用としても用いられる。1 次巻線はインバー 夕に接続されている。基本電源周波数は $60 \mathrm{~Hz}$ で, 推進力 を発生させるため, 振幅の変調を行う。図 2 に巻線の構成

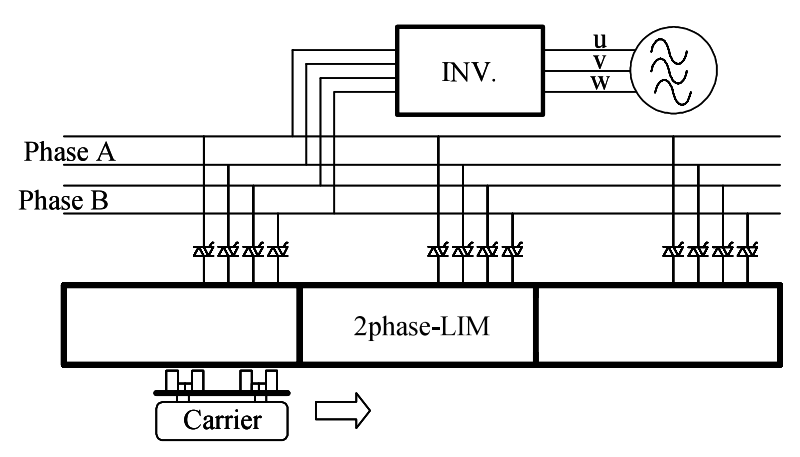

困 1 システム構成

Fig. 1. System configuration. 


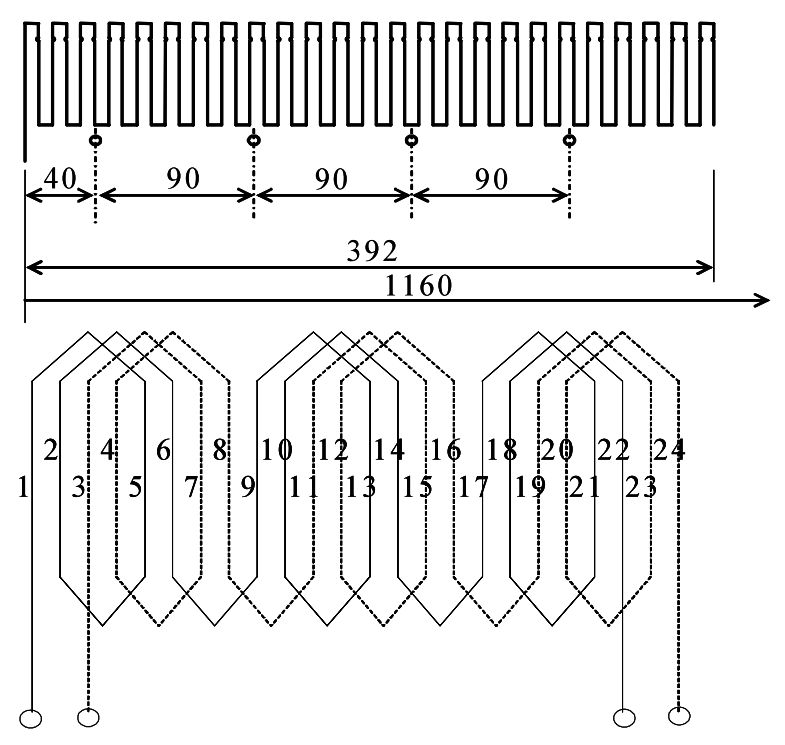

図 2 リア巻線の形状

Fig. 2. Shape of the linear winding.

表 1 リニアモータの諸元

Table 1. Dimension of the linear motor.

\begin{tabular}{c|c}
\hline Voltage and Current & $200 \mathrm{~V} \cdot 5 \mathrm{~A}$ \\
\hline Width and height & $1160 \times 100 \mathrm{~mm}$ \\
\hline Thickness (lamination) & $40 \mathrm{~mm}(0.5 \mathrm{~mm} \mathrm{X} \mathrm{80)}$ \\
\hline Slot number & 72 \\
\hline Turn & 150 \\
\hline Pole pitch & $66 \mathrm{~mm}$ \\
\hline Phase & 2 \\
\hline
\end{tabular}

を示す。それぞれ 2 相の巻線は Phase-A, Phase-B と定義 される。表 1 にリニアモータ諸元を示す。モー夕の長さは $1.16 \mathrm{~m}$ である。

$\langle\mathbf{2} \cdot \mathbf{2}\rangle$ 実験装置の構成 図 3 に実験装置を示す。2 相 リニアモータの 1 次巻線を推進および浮上案内用として設 置する。搬送車側には $2 つ 0 U$ 字鉄心が搭載される。U 字 鉄心の歯幅はリニアモータの磁極ピッチと同じである。U 字鉄心にはコイルが巻かれており，スイッチング用の FET が接続され，その ON-OFFにより吸引力制御を行う。ス イッチングの際大きな誘導起電力が FET に加わるので，並 列に保護抵抗を挿入している。この保護抵抗は U 字鉄心の コイルの電流を変化させるため, 浮上特性に影響を与える。 2 個のレーザーセンサにより U 字鉄心表面と 1 次側コイル の底面間のギャップ（浮上ギャップ）を測定する。これら のギャップデータは $\mathrm{A} / \mathrm{D}$ 変換器を通してパソコンに送られ る。ここでサンプリング周波数は $10 \mathrm{kHz}$ である。

$\langle\mathbf{2} \cdot \mathbf{3}\rangle$ 浮上方式図 4 に浮上原理を示す ${ }^{(6)}$ 。浮上ギヤ ップが小さくなると, FET のスイッチが閉じられる。する と鉄心に巻かれたコイルが短絡することで 1 次側リニア巻 線に流れる交流による磁束変化により発生した誘導起電力 によって電流が流れ，吸引力を減らす方向に磁束が発生す

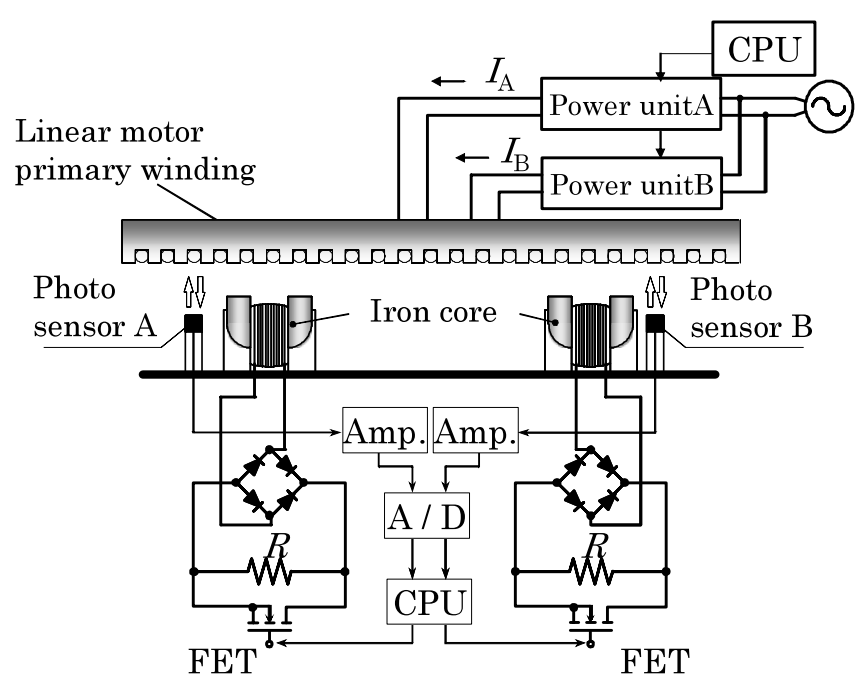

図 3 実験装置

Fig. 3. Experimental device.

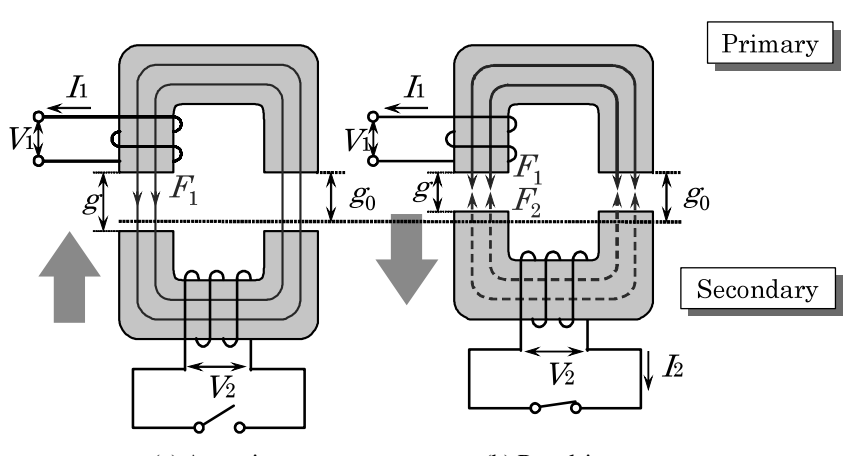

(a) Attractive

(b) Repulsive

図 4 浮上原理

Fig. 4. Principle of the levitation.

る。逆にギャップが目標值よりも大きい場合は FET を OFF にし，吸引力を増加させる。このようにして搬送車側鉄心 の巻線に接続した FET のスイッチングにより浮上ギャップ を制御できる。また，この方法を用いることで浮上制御に 必要なエネルギーは非常に小さくなるため, バッテリーな どを用いると搬送車側に地上からの電源供給の必要がなく なる。

図 5 に浮上ギャップの制御方法を示す。位相面軌跡が示 されており, 横軸は浮上ギャップ, 縦軸は搬送車の上下速度 である。FET が ONの領域では吸引力は小さくなり, OFF の領域では大きくなる。スイッチングの領域を分けるのは 直線 $S$ であり，この傾き $a$ によって収束性が決まる。もし 上下速度を考慮しないと $a$ は無限大になり，ギャップが目 標点の近傍付近で回って収束しない状態もあるため, 上下 速度を考慮することで収束性をよくしている。なお上下速 度はギャップと時刻データから計算で求めている。

図 6 に搬送車の形状を示す。U 字鉄心の端に 1 つずつ レーザーセンサが設置されている。U 字鉄心に巻かれてい るコイルは直径 $0.8 \mathrm{~mm}$ で巻数は 300 である。搬送車はア ルミフレームを骨格とし，アクリル樹脂で作成され，重量 


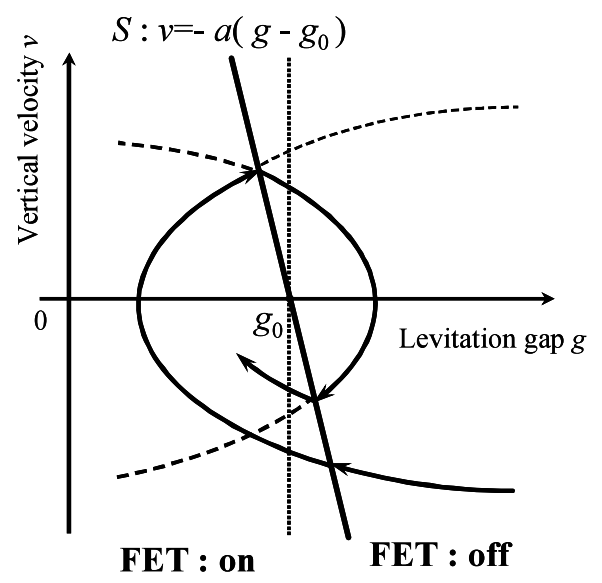

図 5 スイッチング制御方法

Fig. 5. Control method of switching.
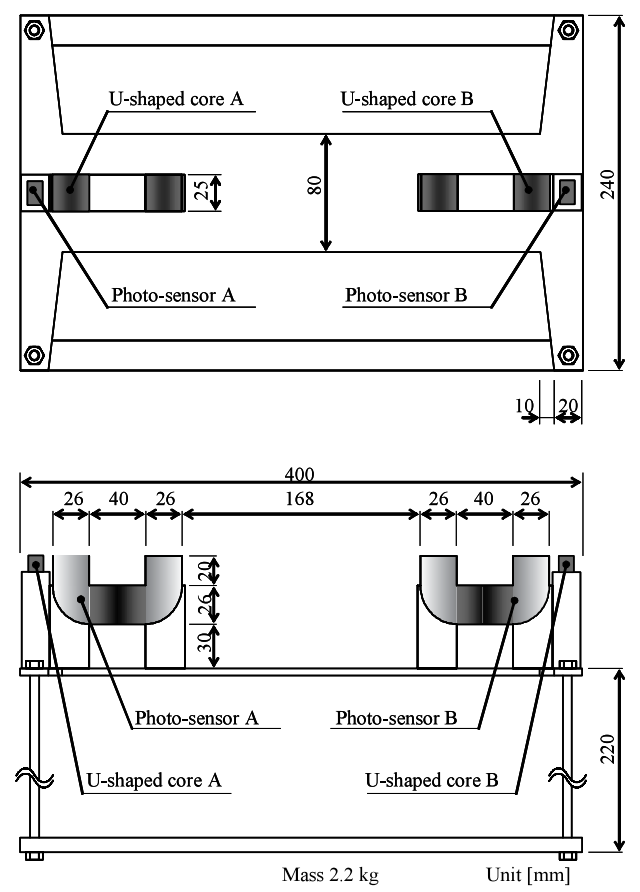

図 6 搬送車形状

Fig. 6. Shape of the carrier (secondary).

は $2.2 \mathrm{~kg}$ である。

$\langle\mathbf{2 . 4}\rangle$ 推進方式 図 7 に推進方法を示す (7)。まず，は じめに一方のリニア巻線, ここでは Phase-A を励磁する（図 中 (a)の状態)。その後 Phase-B の励磁電流を増やすと同時 にPhase-A の電流を減らす。この課程で磁束分布が変化す るために鉄心は図のように右側に移動する（図中 (b) の状 態)。最終的に Phase-A の電流はゼロ, Phase-B の電流が最 大になる (図中 (c) の状態)。この手順を繰り返すことで搬 送車は推進力を得て移動する。図 8 にリニア巻線に流す電 流のパターンを示す。電源電流の振幅が変調されることに より, 推進力が発生する。電流の振動成分は電源の周波数 $(60 \mathrm{~Hz})$ である。振幅の変調周波数を変えることで搬送車 速度を制御できる。リニアモー夕巻線に印加される電源電

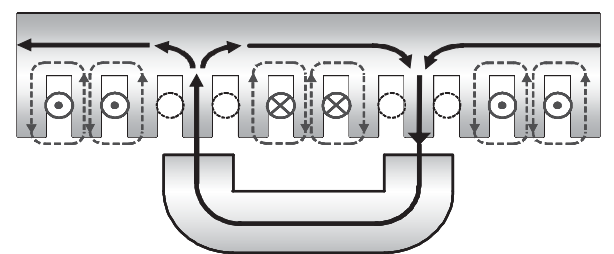

(a) Phase A excited

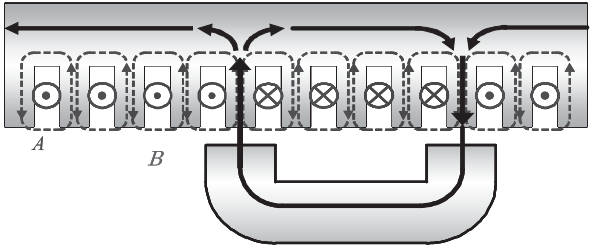

(b) 2-phase excited

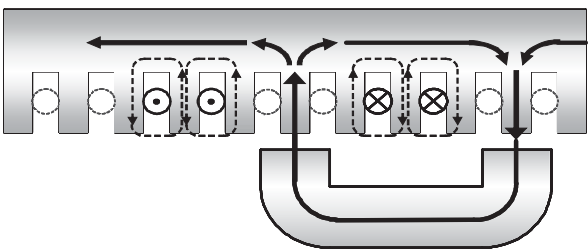

(c) Phase B excited

図 7 推進原理

Fig. 7. Principle of the propulsion.

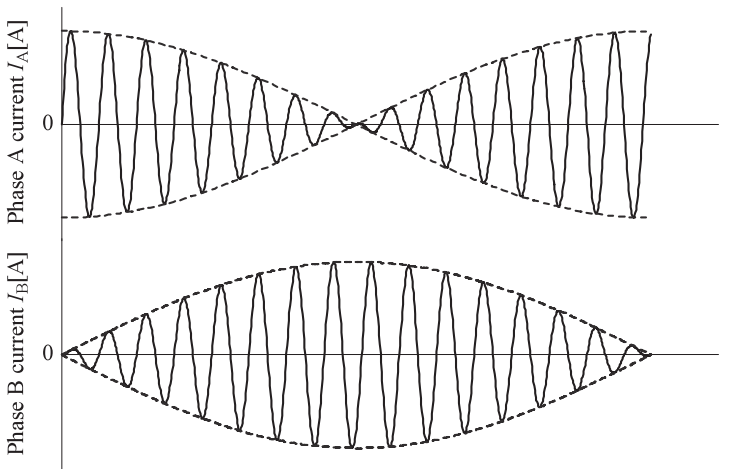

図 8 電流振幅波形変調

Fig. 8. Current pattern applied on the linear winding.

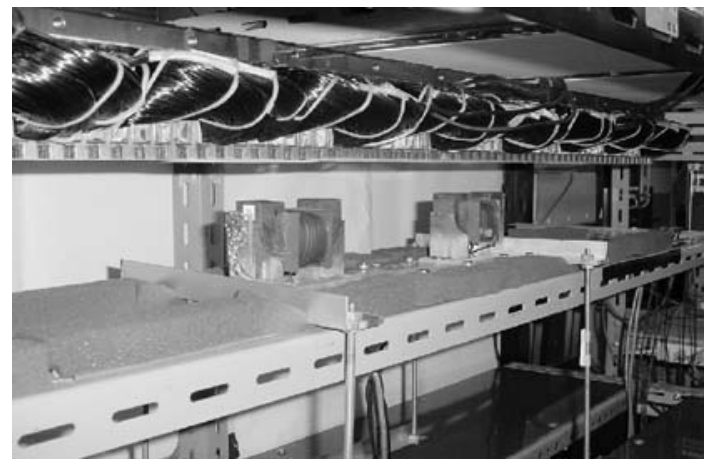

図 9 実験装置図

Fig. 9. Picture of the experimental device. 
流は次式のようになる。

$$
\left.\begin{array}{l}
i_{A}=F_{A}(t) \sin \left(\omega_{1} t\right) \\
i_{B}=F_{B}(t) \sin \left(\omega_{1} t\right)
\end{array}\right\}
$$

ここで $i_{A}$ は Phase-A の電流， $i_{B}$ は Phase-B の電流， $F_{A}$ は Phase-A 電流の振幅, $F_{B}$ は Phase-B 電流の振幅であり, $\omega_{1}$ は基本電源周波数（ここでは商用周波数 $60 \mathrm{~Hz}$ ) である。 推進のための移動磁界を発生させるため, $F_{A}$ および $F_{B}$ は 次式で示される。

$$
\left.\begin{array}{l}
F_{A}=I \sin \left(\omega_{2} t-\pi / 2\right) \\
F_{B}=I \sin \left(\omega_{2} t\right)
\end{array}\right\}
$$

ただし，Iは最大電流， $\omega_{2}$ は振幅変調の周波数である。

このようにしてそれぞれのリニア巻線に振幅を変調した 電流を流す。巻線表面の磁束密度は次式で表される。

$$
B=\frac{8}{\pi} B_{m} \sin \omega_{1} t \cos \frac{\pi}{8}\left\{\cos \left(\omega_{2} t-\theta+\frac{\pi}{8}\right)\right\} \cdots \cdots
$$

ただし， $B_{m}$ は最大磁束密度， $\theta$ は巻線上の位置である。

その結果，最大磁束の位置は $\omega_{2}$ によって変更され，搬 送車の速度制御が可能となる。三相巻線を用いればもっと 簡単に移動磁界が発生するが，搬送車の停止状態と移動状 態での吸引力の差の制御が難しいため，本システムではこ の方式を採用した。図 9 に実験装置図を示す。

\section{3. 実験装置}

〈3・1〉磁束密度分布 図 10 にリニア巻線での磁束分

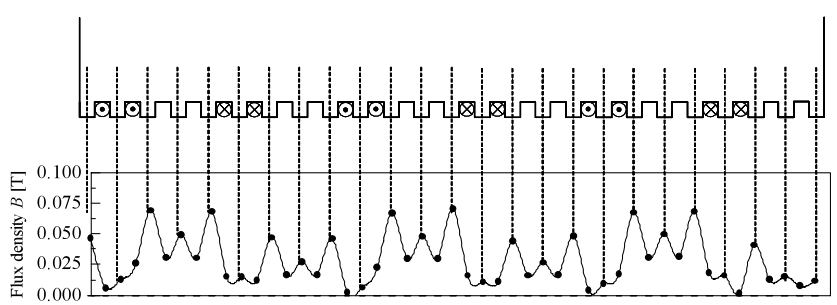

(a) Phase A excited

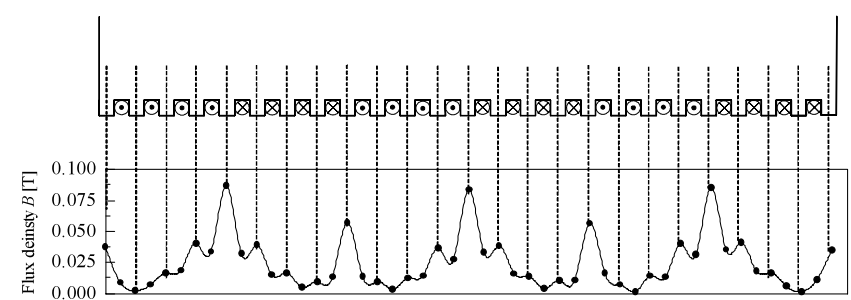

(b) Both phase A and B excited

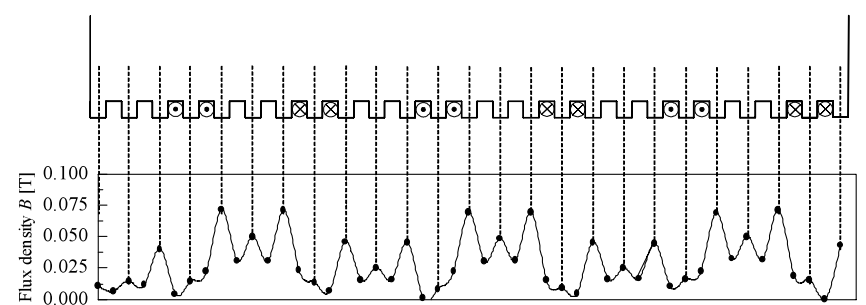

(c) Phase B excited

図 10 リニアモータ上の磁束分布

Fig. 10. Flux density distribution on the linear motor.

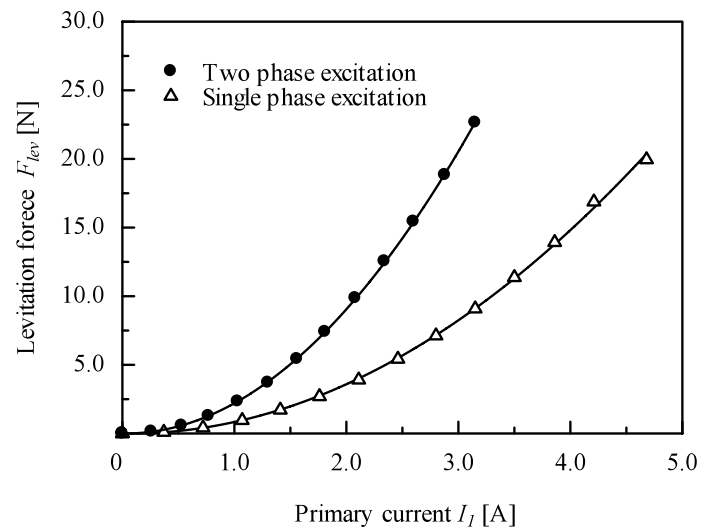

図 11 浮上力

Fig. 11. Levitation force $(g=3.5 \mathrm{~mm})$.

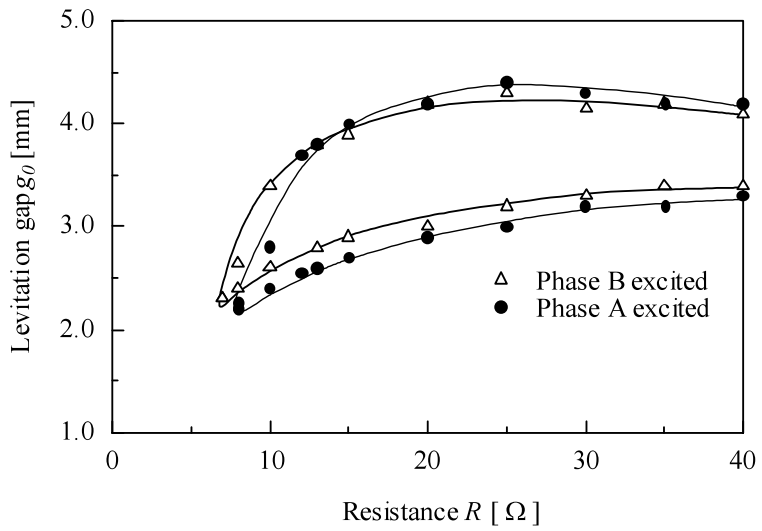

(a) Phase A or B excited
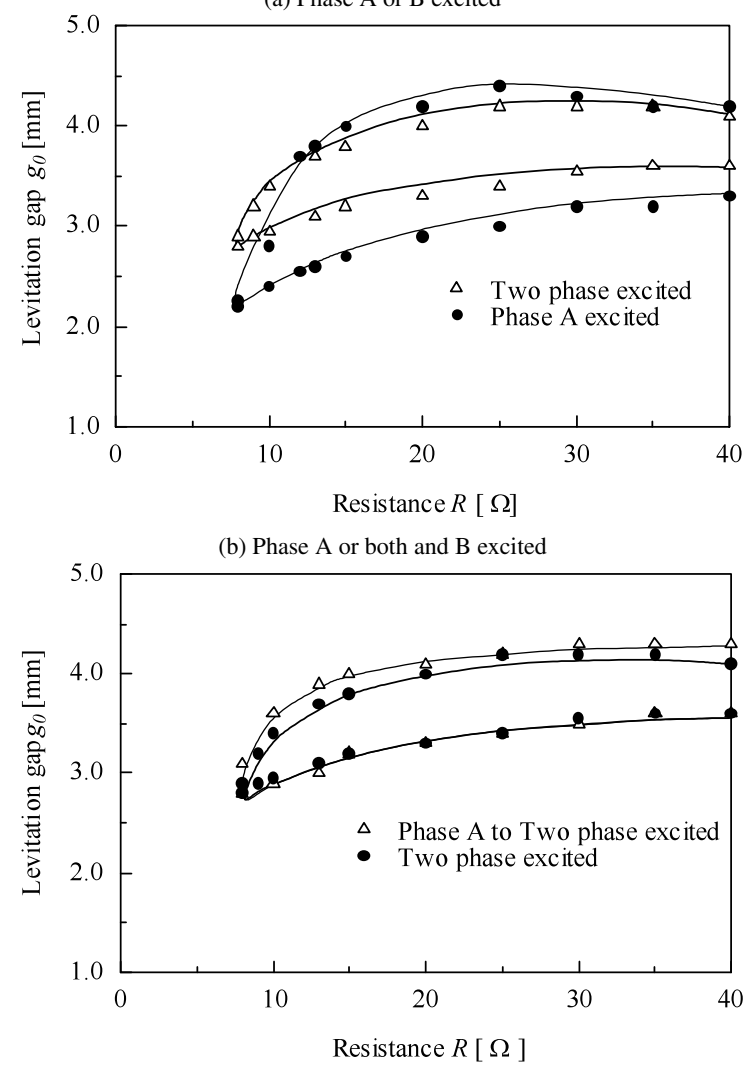

(c) Phase A or both and B excited, U-shape core is set between the slot

困 12 浮上領域

Fig. 12. Levitation region. 


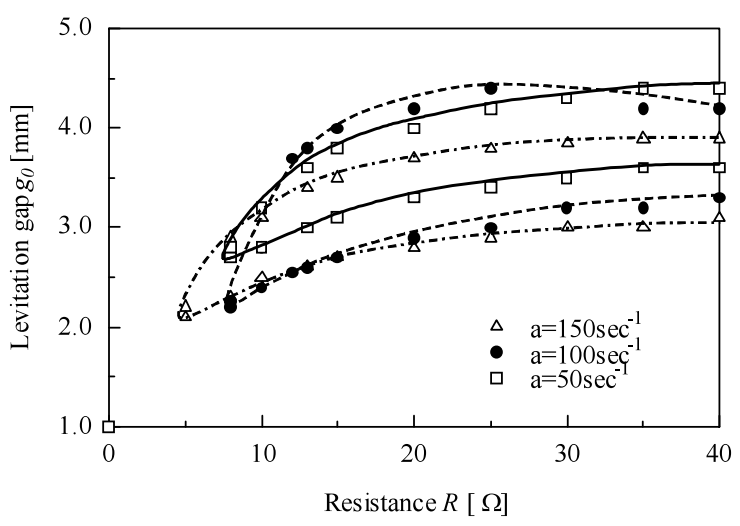

図 13 浮上領域の切替直線傾き依存性

Fig. 13. Dependence of the levitation region on $a$.

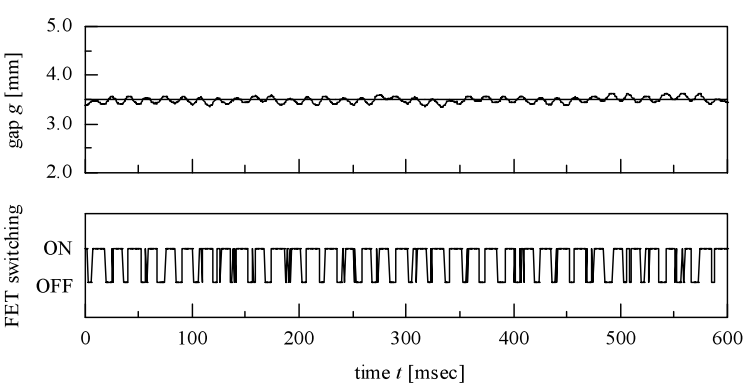

(a) Position of the Sensor A

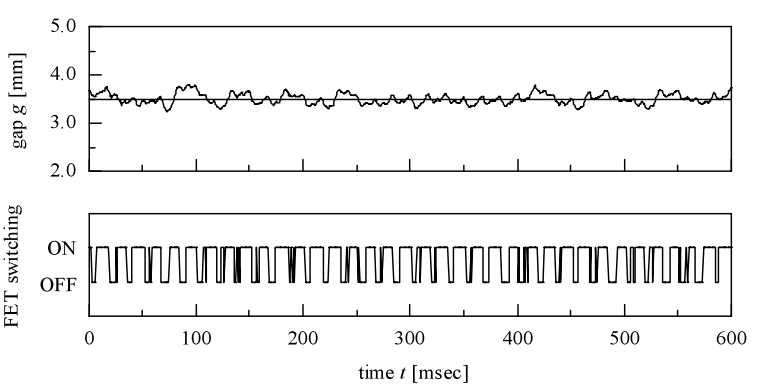

(b) Position of the Sensor B

図 14 浮上特性

Fig. 14. Levitation characteristics.

布を示す。磁束の測定にはホール素子を用いた。図 10(a) および (c) の Phase-A もしくは B のみの励磁では電流值 $4.42 \mathrm{~A}$ を用いた。図 10(b) での両方励磁 (2 相励磁) の場 合の電流值は $2.92 \mathrm{~A}$ を用いている。磁束分布の最大值が移 動し，推進力が発生していることが示されている。

$\langle\mathbf{3 \cdot 2}\rangle$ 浮上領域 図 11 に浮上ギャップ $\mathrm{g}=3.5 \mathrm{~mm}$ の場合の浮上力を示す。ここでU 字鉄心に設置されたコイ ルの FET は OFF となっており，影響はない。このデー夕 から 1 次コイルに供給する電流值の概算を出すことができ る。次に搬送車の浮上領域を図 12 と図 13 に示す。グラフ の横軸は抵抗值である。この抵抗は図 3 に示したFET と 並列に挿入されたものでFET をスイッチングの際の過電圧 から守るためである。この抵抗の值は FET が OFF の場合 の浮上力にも影響を与えるため，この值も検討する必要が ある。縦軸は目標浮上ギャップである。図中の線が浮上成

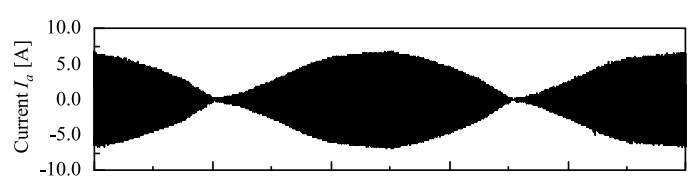

(a) Current of the Phase (A)

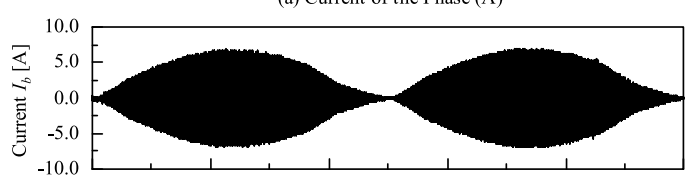

(b) Current of the Phase (B)

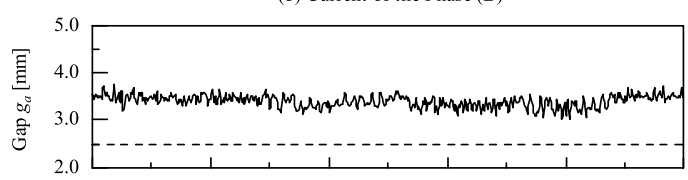

(c) Displacement of the sensor (A)

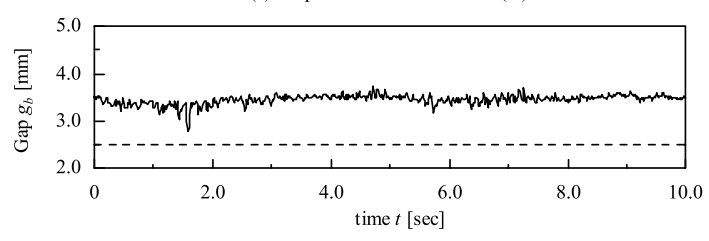

(d) Displacement of the sensor (B)

図 15 浮上状態での浮上 $(v=12.8 \mathrm{~mm} / \mathrm{sec})$

Fig. 15. Levitation gap $(v=12.8 \mathrm{~mm} / \mathrm{sec})$.

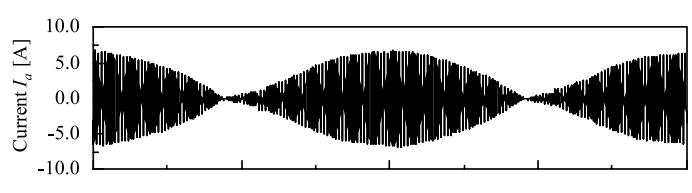

(a) Current of the Phase (A)

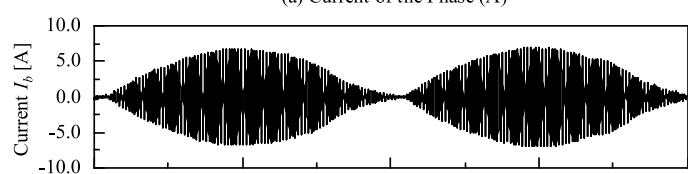

(b) Current of the Phase (B)

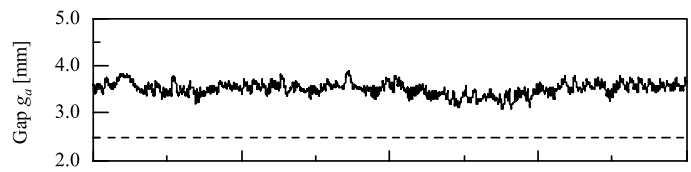

(c) Displacement of the sensor (A)

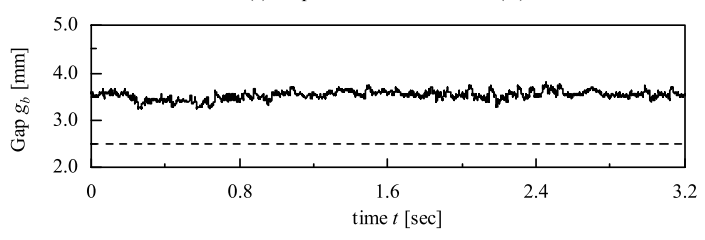

(d) Displacement of the sensor (B)

図 16 推進状態での浮上 $(v=38.4 \mathrm{~mm} / \mathrm{sec})$

Fig. 16. Levitation gap $(v=38.4 \mathrm{~mm} / \mathrm{sec})$.

功と失敗の境界線である。線で囲まれた内部が浮上可能領 域で，外部は落下もしくは 1 次側への吸着により浮上がで きない領域である。境界線は 5 回の実験の平均値が示され ている。

Phase-A と B でインピーダンスの相違があるため，そ れぞれ単独で励磁した場合の浮上領域は完全には重ならな 


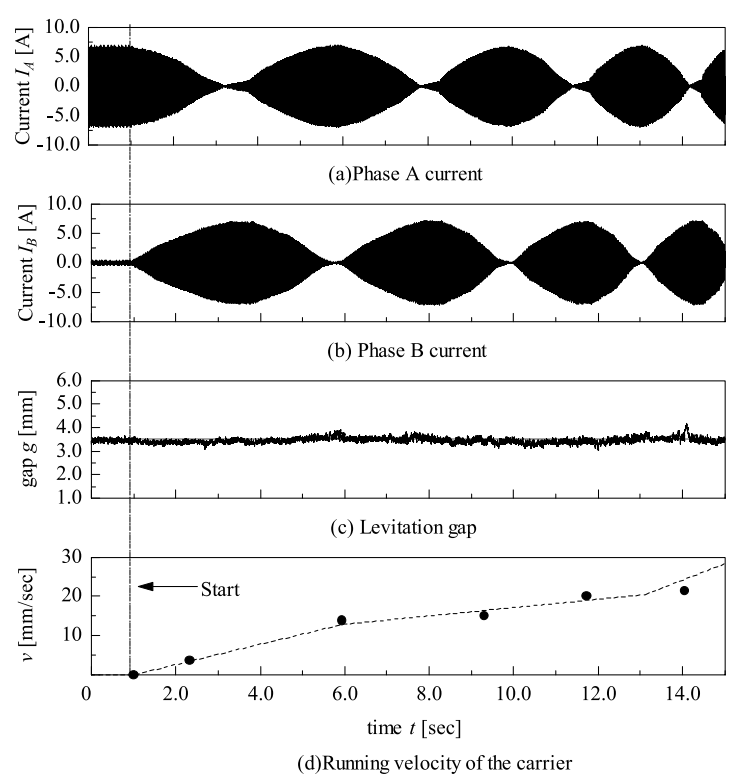

図 17 加速状況下での浮上特性

Fig. 17. Levitation characteristics under acceleration.

い。眓 12(a)にそれぞれの相を単独で励磁した場合，(b)に Phase-Aのみ励磁した場合と両方を励磁した場合（2 相励 磁), (c) にU 字鉄心がリニア巻線のスロットの間に配置さ れた場合の結果を示す。電流值はく3・1〉節で示した值を用 いている。図 12(c) は Phase-A 励磁から 2 相励磁する状態 へ移行しつつある状態と 2 相励磁状態との比較である。す べて推進方向に対しては停止状態であるが，このすべての 励磁状態に対して重なる浮上領域が存在することが確認で きる。つまりリニア巻線上を移動をしながら浮上をするこ とが原理的に可能であることが示された。眓 13 には図 5 で示したスイッチングの切替直線の傾き $a$ の浮上領域への 依存性を示す。図より境界となる線で囲まれた浮上領域は $a=1001 / \mathrm{sec}$ で最大となる。よってこの值を実験で用いる。

$\langle\mathbf{3} \cdot \mathbf{3}\rangle$ 搬送車走行時の浮上図 14 に搬送車の浮上 ギャップと FET のスイッチング波形を示す。搬送車の前 方と後方につけられた 2 つセンサ A，Bの值を示す。こ のシステムではピッチングの発生が想定される問題のひと つであるが，大きなピッチング運動が発生していないこと が図より示されている。困 15 と図 16 に巻線に流れる電流 と浮上ギャップの様子を示す。ここで電源には推進のため の振幅変調が行われており, 図 15 については変調周波数 $\omega_{2}=0.1 \mathrm{~Hz}$ で $10 \mathrm{sec}$ 間, 図 16 では $\omega_{2}=0.3 \mathrm{~Hz}$ で $3.2 \mathrm{sec}$ 間の浮上状態を示している。よって, 搬送車の速度は $0.1 \mathrm{~Hz}$ の場合で $12.8 \mathrm{~mm} / \mathrm{sec}, \quad 0.3 \mathrm{~Hz}$ の場合で $38.4 \mathrm{~mm} / \mathrm{sec}$ とな る。この結果から, 搬送車が各速度で浮上しながら推進す ることが確認でき，ピッチング角も少ないことが示された。 本システムでは搬送車側の U 字鉄心が浮上も兼ねているた め推進なしの場合と比較すると浮上ギャップの振動は大き くなっているが，安定した浮上を実現している。また，推 進速度が速いほうが浮上状態は安定している。先に示した
ように浮上にはスイッチングの切替直線の傾き $a$ と FET に 並列に挿入する抵抗 $R$ の值が影響を与える。よって, 各推 進速度における最適值について今後検討を行う必要がある。 図 17 に加速状態にある場合の浮上特性を示す。加速度が 大きい場合には浮上状態が若干乱れ, 目標值から多少ずれ るが，すぐに目標值付近に復帰し，浮上し続ける。

\section{4. まとめ}

2 相リニアモータを用いた磁気浮上搬送システムを取り 上げた。このシステムでは浮上系と推進系を統合させるこ とができる。浮上および推進の原理が示された。また，リ ニアモータの各励磁状態における浮上可能領域を測定した。 リニアモータ 1 次巻線の電流に振幅変調を加えることで同 時に推進を行うことができ，完全非接触搬送が実現した。 搬送車側には FET のスイッチング用電力しか必要でないた め, 電源の供給も不要となる。浮上を行いながら各推進速 度において安定な走行を実現した。また加速状態での安定 浮上についても確認した。今後の課題としてはスイッチン グ状態を決定するパラメータおよびFETに接続する抵抗の 值の速度依存性や，浮上安定性の向上があげられる。

本研究の一部は平成 16 年度関西大学在外研究による成 果である。

(平成 17 年 9 月 22 日受付，平成 17 年 12 月 22 日再受付)

\section{文献}

(1) T. Azukizawa, M. Morishita, S. Kanda, N. Tamura, and T. Yokoyama: "A Linear Induction Motor Control System for Magnetically Levitated Carrier System", IEEE Trans. on Vehicle Tech., Vol.38, No.2, pp.102-108 (1989)

（2）正田英介·藤江恂治·加藤純郎 - 水間 毅：磁気浮上鉄道の技術, オーム社 (1992)

（3）電気学会：磁気浮上と磁気軸受, コロナ社 (1993)

(4) T. Hikihara, T. Uejyou, and Y. Hirane: "An Experimental Study on Driving Characteristics of Attraction-type Magnetically Levitated Carrying System", T. IEE Japan, Vol.115-D, No.3, pp.282-286 (1995-3) (in Japanese) 引原隆士 ·上條武史・平根喜久:「交流吸引形浮上搬送兼用 LIM 9 走行実験」, 電学論 D, 115, 3, pp.282-286 (1995-3)

(5) S. Ohashi: "Levitation characteristics of the magnetically levitated conveyance system using two phase linear motor", Proceedings of 35th IEEE Power Electron. Specialists Conference (PESC 2004), pp.1881-1886 (2004)

(6) S. Ohashi, E. Asao, and H. Hirane: "Levitation Characteristics of Attractiontype Magnetically Levitated Carrying System", Proc. of Int. Symposium on Linear Drives for Ind. Appl. (LDIA'98), pp.323-326 (1998)

(7) S. Ohashi: "Control Method of the Propulsion System for the Magnetically Levitated System with Linear Motor", Proc. of the 2005 Int. Power Electron. Conference (IPEC-Niigata 2005), pp.865-870 (2005)

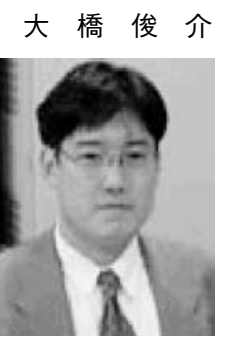

（正員） 1969 年 10 月 20 日生。1992 年東京大学 工学部電気工学科卒。1997 年同大学大学院工学 系研究科電気工学専攻博士課程修了。同関西大学 工学部助手, 2000 年同専任講師, 2003 年同助教 授, 現在にいたる。1997 年 3 月工学博士。主とし て, 磁気浮上システム, 超電導応用, リニアモー 夕の研究に従事。IEEE 会員。 